\title{
Dinomys branickii Peters, 1873 (Rodentia, Dinomyidae): consumption and food preference in captivity
}

\author{
Raymundo Tomaz Melo dos Santos Neto ${ }^{{ }^{*}}$ \\ Valber Cleyton Leal da Costa ${ }^{1}$ \\ Áurea Martins Gabriel ${ }^{2}$ \\ Diva Anelie de Araújo Guimarães ${ }^{1}$

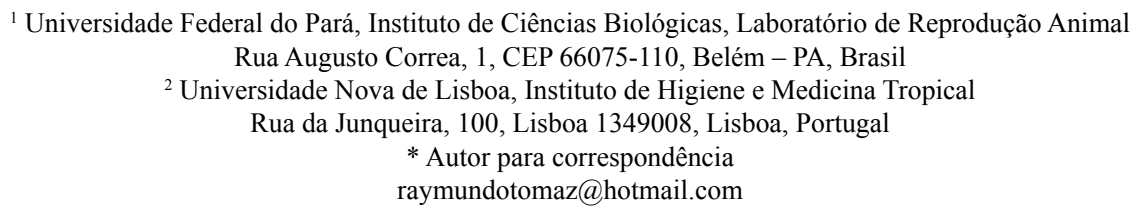

Submetido em 31/03/2016

Aceito para publicação em 13/12/2016

\section{Resumo}

Dinomys branickii Peters, 1873 (Rodentia, Dinomyidae): consumo e preferência alimentar em cativeiro. Dinomys branickii é uma espécie vulnerável que sofre pressão de atividades antrópicas como a caça e a destruição do habitat. A criação dessa espécie em cativeiro é uma alternativa viável para a implantação de projetos de conservação e para ampliar o conhecimento dos principais aspectos da sua biologia. $\mathrm{O}$ objetivo deste trabalho foi determinar o consumo e a preferência alimentar de um grupo de $D$. branickii em cativeiro. Para determinar a preferência alimentar foi utilizado o índice de preferência alimentar $(\mathrm{P})$ dos alimentos mais consumidos. A quantidade média de alimentos ofertados foi de $6,6 \mathrm{~kg}$ dia/grupo, sendo consumidos $4,4 \mathrm{~kg} \mathrm{dia} /$ grupo (66\%), totalizando $11 \pm 2,9$ alimentos ofertados por dia. O consumo de frutas (71\%) foi maior que os demais grupos alimentares, seguido do consumo raízes/tubérculos $(65,3 \%)$ e os menos consumidos foram cereais/ sementes (39,4\%) e folhas (38,3\%). Os alimentos preferidos foram: Brassica oleracea $(\mathrm{P}=1,38)$, Zea mays $(\mathrm{P}=1,25)$, Ipomoea batatas $(\mathrm{P}=1,17)$, Mangifera indica $(\mathrm{P}=1,13)$, Cucubita moschata $(\mathrm{P}=1,10)$, Talinum esculentum $(\mathrm{P}=1,00)$ e Manihot esculenta $(\mathrm{P}=1,00)$. Os resultados obtidos sugerem que os alimentos com teor elevado de fibras e carboidratos devem ser utilizados na composição da dieta de $D$. branickii em cativeiro, visando o bem estar e desenvolvimento da espécie.

Palavras-chave: Alimentação; Bem-estar animal; Ex-situ; Manejo em cativeiro; Nutrição

\section{Abstract}

Dinomys branickii is a large rodent listed as Endangered (EN), that suffers pressure from anthropogenic activities such as hunting and habitat destruction. Captive breeding methods are viable for supplementation of conservation projects, and may enhance our knowledge of main aspects of the biology of this species. The objective of this study was to determine consumption and food preferences in a captive group of $D$. branickii. To determine feeding preferences, the Food Preference Index (P) was used for the type of food with highest 
consumption. The mean amount of food provided was $6.6 \mathrm{~kg}$ per day per group, with $4.4 \mathrm{~kg}$ per day/group consumed (66\%). An average of $11 \pm 2.9$ types of food were offered daily. The consumption of fruits $(71 \%)$ was higher than the consumption of other food groups, followed by roots/tubers $(65.3 \%)$. The food groups least consumed were cereals and seeds (39.4\%) and leaves (38.3\%). The preferred foods were: Brassica oleracea $(\mathrm{P}=1.38)$, Zea mays $(\mathrm{P}=1.25)$, Ipomoea batatas $(\mathrm{P}=1.17)$, Mangifera indica $(\mathrm{P}=1.13)$, Cucurbita moschata $(\mathrm{P}=1.10)$, Talinum esculentum $(\mathrm{P}=1.00)$ and Manihot esculenta $(\mathrm{P}=1.00)$. These results suggest that foods with high fiber and carbohydrate content are the best choices for $D$. branickii development and well-being in captivity.

Key words: Ex-situ; Feeding; Nutrition; Rearing in captivity; Welfare

\section{Introduction}

The pacarana (Dinomys branickii) is the only rodent species from the Family Dinomyidae, and has restricted occurrence in South America including parts of Bolivia, Brazil, Colombia, Ecuador and Peru (CONSELHO NACIONAL DE PESQUISA, 1991). In Brazil, it occurs exclusively in western Amazon in the states of Acre, Rondônia, and southeast Amazonas, and is thought to also occur in Mato Grosso do Norte (EMMONS; FEER, 1990).

This species is rarely seen in the natural habitat, so records of occurrence are usually based on footprints (SÁNCHEZ et al., 2004) and information obtained from interviews with local community members where they occur (PACHECO et al., 2007). According to the International Union for Conservation of Nature (IUCN, 2015), this species is considered vulnerable and susceptible to extinction due to factors such as hunting for meat consumption, demographic growth of local traditional populations, and deforestation (TIRIRA et al., 2008). Despite these threats, this species is currently not on the list of endangered species in Brazil, perhaps due to sparsity of data Chiarello et al. (2008).

Captive breeding of $D$. branickii has emerged as a way to learn about its biology and feeding behavior, and resulting data may contribute to the development of adequate protocols for ex-situ management practices. The viability of captive breeding is limited by gaps in our knowledge of nutritional requirements of this species, and this information is crucial for maintenance of growth, development and reproduction (CAVALCANTE et al., 2005; ANTONIO et al., 2007). Establishing a balanced diet is important for promoting the health, well-being, longevity, and reproductive success of captive animals, since adequate and appropriate nutrition is essential to meet metabolic needs and maintain vital functions (CARCIOFI; OLIVEIRA, 2007). Development of an effective ex-situ production system will also require knowledge of nutritional requirements for the species (ANTONIO et al., 2007).

There are few studies on adequate nutritional provision for wild species kept in captivity, particularly about the feeding habits and nutritional demands of native wild species compared to domestic livestock (DIERENFELD, 1997; CHEEKE; DIERENFELD, 2010). This lack of knowledge may complicate breeding in captivity and the development of conservation strategies. However, recent studies have elucidated some previously unknown aspects of the digestive system physiology of some wild rodents as well as requirements and preferences for nutrition and food, including Hydrochoerus hydrochaeris (RODRIGUES et al., 2006), Chinchilla laniger (ANTONIO et al., 2007), Cuniculus paca (LASKA et al., 2003; ZUCARATTO et al., 2010) and Dasyprocta leporina (CAVALCANTE et al., 2005; McWILLIAMS, 2009). There have been advances in the composition of industrialized food for Cavia porcellus, Mus musculus and C. laniger due to their popularity as pets.

Dinomys branickii is one of the wild rodents that is almost completely unknown to science, and what little is known about this animal comes from just a few zoological parks located in Zurich-Switzerland, San Antonio, USA (COLLINS; EISENBERG, 1972), and Colombia (LÓPEZ et al., 2000; OSBAHR; MEJÍA, 2001). López et al. (2000) confirmed nocturnal habits in this species by studying social behavior in captivity. Osbahr and Mejía (2001) analyzed digestive capability by determining concentrations of calcium, iron, protein, fat, fibers, and ashes in the digestive system. The authors 
suggested that the requirements for this species are $0.4 \%$ calcium and $6.5 \%$ protein, and that it has high digestive capacity for raw fiber. Concerning food preference, Saavedra-Rodríguez et al. (2012) reported the use of 18 plant species by $D$. branickii. Consumption in situ included foliage, fruits, ferns (stems and rhizomes), herbs, shrubs, and trees; this is one of the few studies on this subject.

Greater knowledge of ecological aspects and proper handling with respect to nutrition in captive wild species is fundamental for survival and reproduction of natural populations (OSBAHR; MEJÍA, 2001). The objective of the present study was to determine diet composition and food preferences of $D$. branickii in captivity, with the goal of better understanding species feeding habits. These results may help us to develop a nutritional handling protocol for successful maintenance of this species in captivity.

\section{Materials and Methods}

\section{Animals and study location}

The study was conducted at the Bioparque Amazônia - Crocodilo Safari Ltda Zoo, in Belém, Pará, northern Brazil. The $D$. branickii family group kept in captivity is composed of six members: four adults (two males and two females) and two pups. Both female and male breeders were transferred to this facility by the Chico Mendes Institute for Conservation and Biodiversity (ICMBio) in Acre. The young male and two pups were born in captivity.

The animal facility contains two separate but connected areas with brick walls $(0.3 \mathrm{~m}$ high), steel screens $(0.8 \mathrm{~m}$ high $)$, and a tile roof. The shelter and feeding area was covered (1.1 m sq.) and the open area (3.6 m sq.) had tree trunks, a dirt floor, and a water tank. The areas were connected through an entrance and exit pathway (Figure 1).

FIGURE 1: The animal facility at the Bioparque Amazônia Crocodilo Safari Ltda Zoo. A: The shelter and feeding area; B: The open area. $\mathrm{m}=$ meter. Source: Diva Guimarães.

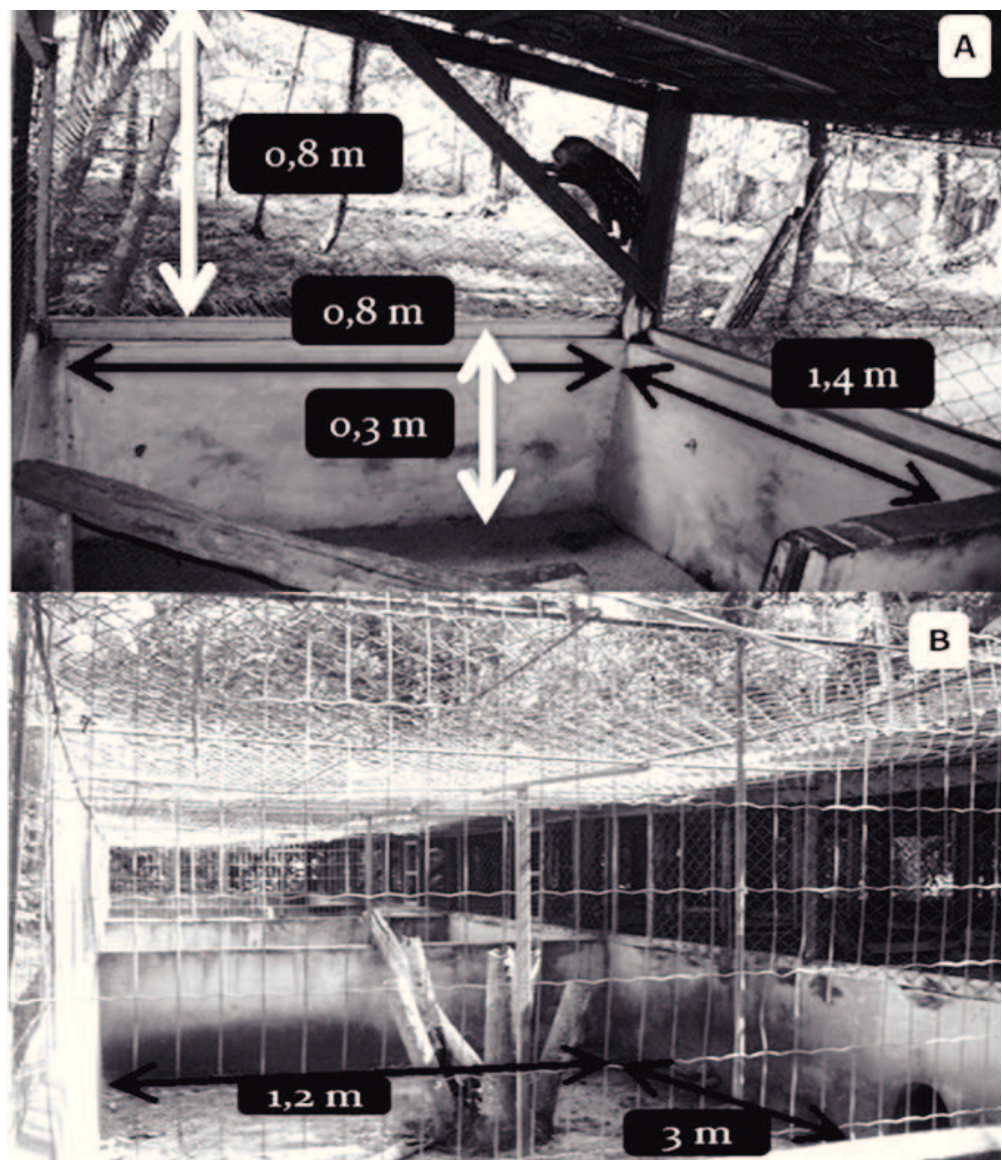




\section{Experimental design}

\section{Experiment 1: Food consumption}

We considered information on the diet in natural settings, which is composed mainly of fruit, leaves and stems (NOWAK, 1991), and the information from Osbahr and Mejía (2001) on digestibility and food preferences of captive $D$. branickii, we formulated a composition of daily ad libitum supply that included in accordance with local availability at least 10 of the following foods: 1 - Fruit: Ananas comosus, Astrocaryum aculeatum, Averrhoa carambola, Carica papaya, Citrullus lanatus, Citrus aurantium, Cucumis melo, Cucumis sativus, Cucurbita moschata, Endopleura uchi, Mallus comunis, Mangifera indica, Mauritia flexuosa, Musa spp., Psidium guajava. 2 - Leaves: Brassica oleracea, Brassica oleracea var. capitata, Talinum esculentum; 3 - Roots/ Tubers: Ipomoea batatas, Daucus carota, Manihot esculenta, Solanum tuberosum; 4 - Cereals/Seeds: Carapa guianensis, Hevea brasiliensis and Zea mays.

Observation of food consumption took place four times a week for four months, totaling 64 samples. Food was cut into large and small pieces which were weighed using digital scales (Urano ${ }^{\circledR}$ Automoção Comercial and Balanças Eletrônicas, Vila Rosa-Canoas/ RS, Brazil). Food was offered to the family once a day, in the morning. Daily food intake was obtained by subtracting the total weight of supplied food by the weight of leftover food after $24 \mathrm{~h}$. The most and least consumed food was determined by percentage $(\%=$ total weight of each type of food consumed /total weight of each type of food supplied x 100). Food was supplied in two metallic bowls ( 36 and $33 \mathrm{~cm}$ diam.).

\section{Experiment 2: Food preference}

Food used in this study was among those most consumed regarding the family group, observed in Experiment 1 (food consumption). The following foods were offered: C. moschata (1500 g), Musa spp. (800 g), C. papaya (1000 g), C. lanatus (500 g), T. esculentum (400 g), B. oleracea (400 g), I. batatas (600 g), S. tuberosum (600 g), M. esculenta (600 g), and Z. mays (400 g).
The Food Preference Index (P) was used to determine family group food preferences, where $\mathrm{P}=\mathrm{FD}$ / FR; FD = weight consumed of each type of food/total weight of food consumed and FR = weight of each type of food supplied/total weight of food supplied (PERISSÉ et al., 1989). The value of $\mathrm{P}$ varied from 0 to 2 , where $\mathrm{P}$ $\geq 1$ corresponded to preferred items; that is, food with $\mathrm{P}$ values close to 2 were classified as the most preferable.

Food was provided once a day for 10 consecutive days, and was cut into big and small pieces so that both adults and pups could eat. The foods were mature, and were evaluated by the zookeeper prior to offering. No other types of foods were offered during this study period. This experiment was carried out in accordance with the Guide for the Care and Use of Laboratory Animals (NATIONAL RESEARCH COUNCIL, 2011).

\section{Statistical analysis}

To evaluate variations in consumption of food groups, differences between the daily quantity of food offered and the quantity of leftover food were compared using a Kruskal-Wallis test with a post-hoc Dunn test. Food preference comparisons were done using ANOVA with a post hoc Tukey test. The comparison of food preferences was performed by analysis of variance (ANOVA) with a Tukey's honestly significant difference (HSD) post hoc test. All statistical procedures were done in BioEstat ${ }^{\circledR}$ version 5, with a significance level of $0.05 \%$.

\section{Results}

The average daily food quantity supplied was $6.6 \mathrm{~kg}$ per group, and average daily consumption was $4.4 \mathrm{~kg}$ (67\% of the total amount supplied). Daily food offered to the family group consisted of the following proportions: fruit $=6.4 \pm 2.1(61 \%)$, roots/tubers $=2.1 \pm$ $0.8(24 \%)$, leaves $=0.8 \pm 1.0(9 \%)$, and cereals $/$ seeds $=$ $1.8 \pm 1.1(6 \%)$, for an average of $11 \pm 2.9$ different types of food. The consumption of fruits was highest (71\%, $\mathrm{p} \leq 0.05 ; \mathrm{H}=154.6$ ), and consumption of roots/ tubers was second highest $(65.3 \%)$. These food were consumed significantly more than of grains and seeds consumption (39.4\%) and leaves $(38.3 \%)(\mathrm{p} \leq 0.05, \mathrm{H}=154.6)$. There 
was no significant difference in consumption of leaves versus grains/seeds ( $\mathrm{p} \geq 0.05 ; \mathrm{H}=154.6)$ (Figure 2).

Using descriptive methods, the most consumed fruits were: M. comunis (89.5\%), C. papaya (86\%), C. moschata (84\%), Musa spp. (76\%) and C. lanatus (63\%). Endopleura uchi (2\%), P. guajava (5\%), C. aurantium (9.5\%), A. comosus (12\%), M. flexuosa (22\%), C. sativum (28\%), and A. carambola (32\%) were the least consumed. The most consumed leaves were of the following species: B. oleracea $(88 \%)$ and
T. esculentum $(72 \%)$, and B. oleracea var. capitata was the least consumed (34\%). The most consumed roots/ tubers were $S$. tuberosum (82\%), I. batatas (79\%) and M. esculenta (68.5\%), while D. carota (56\%) was the least consumed. The most consumed cereal/seed was Z. mays $(49 \%)$ while $C$. guianensis $(0.6 \%)$ and $H$. brasiliensis $(1.3 \%)$ were the least consumed. Regarding food preference, seven foods had high food preference index values $(\mathrm{P} \geq 1)$, while only three had low preference values $(\mathrm{P}<1)$ (Table 1$)$.

FIGURE 2: Consumption of food groups by a captive $D$. branickii family group. The circles represent average consumption of each food group, including fruits $(n=65)$, roots/tubers $(n=63)$, leaves $(n=31)$ and cereals/seeds $(n=36)$.

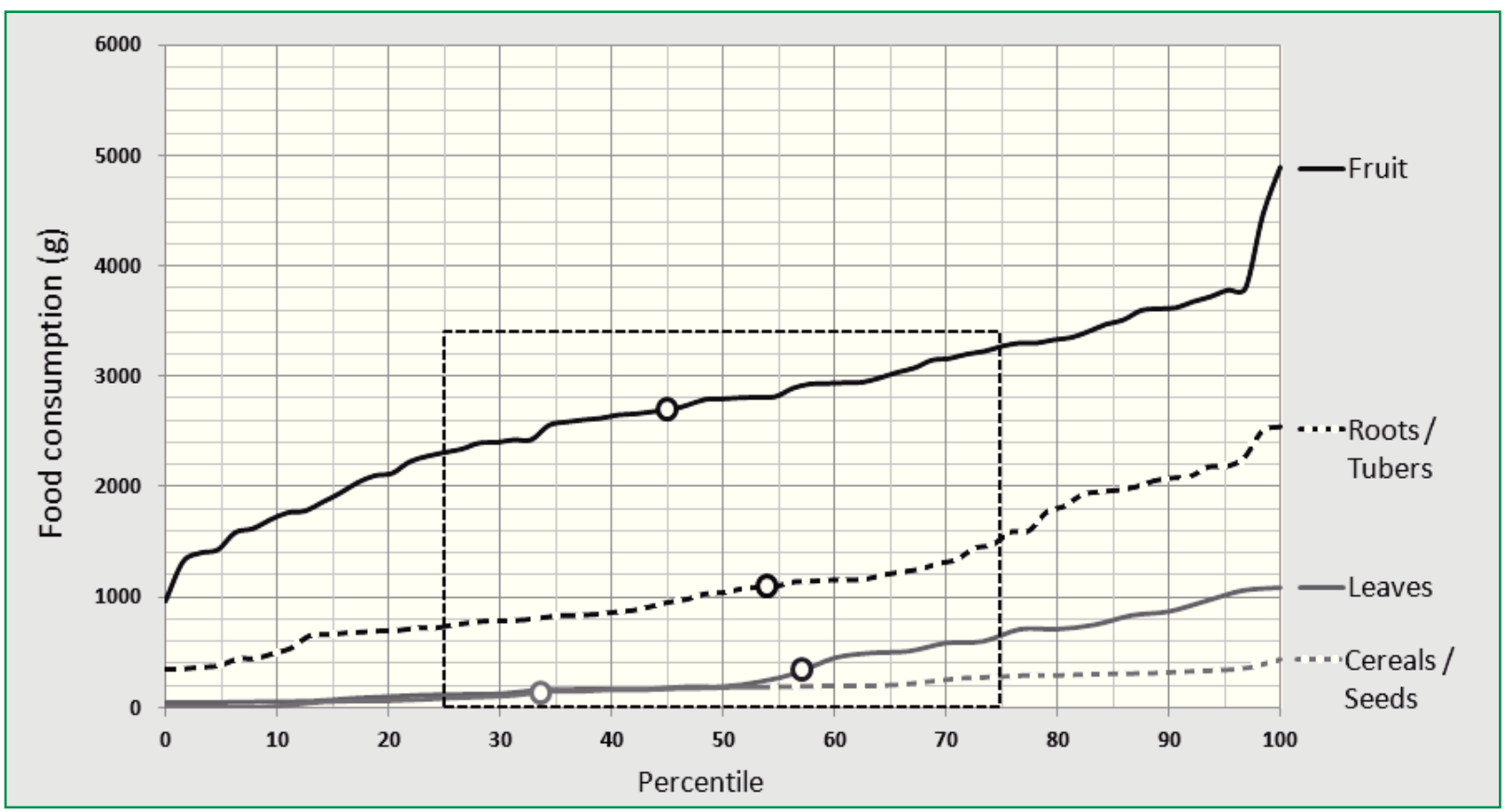

TABLE 1: Food Preference Index and food consumption of a captive Dinomys branickii family group.

\begin{tabular}{lccccc}
\multicolumn{1}{c}{ Foods } & FS $(\mathbf{g})$ & $\mathbf{n}$ & $\mathbf{P}$ & $\mathbf{A}(\mathbf{\%})$ & C $(\mathbf{g})$ \\
\hline B. oleracea & 400 & 10 & $1.38 \pm 0.09$ & $91.4 \pm 7.4$ & $366 \pm 29$ \\
Z. mays & 400 & 10 & $1.25 \pm 0.15$ & $83.0 \pm 6.3$ & $332 \pm 25$ \\
I. batatas & 600 & 10 & $1.17 \pm 0.23$ & $77.5 \pm 12.9$ & $465 \pm 77$ \\
C. papaya & 1000 & 10 & $1.13 \pm 0.21$ & $75.1 \pm 10.1$ & $751 \pm 101$ \\
C. moschata & 1500 & 10 & $1.10 \pm 0.14$ & $72.9 \pm 13.3$ & $1093 \pm 200$ \\
T. esculentum & 400 & 10 & $1.00 \pm 0.12$ & $65.0 \pm 10.0$ & $260 \pm 40$ \\
M. esculenta & 600 & 10 & $1.00 \pm 0.24$ & $64.4 \pm 16.3$ & $386 \pm 98$ \\
C. lanatus & 500 & 10 & $0.74 \pm 0.10$ & $48.8 \pm 8.2$ & $244 \pm 41$ \\
Musa spp. & 800 & 10 & $0.71 \pm 0.20$ & $47.2 \pm 15.3$ & $378 \pm 123$ \\
S. tuberosum & 600 & 10 & $0.60 \pm 0.18$ & $39.7 \pm 12.8$ & $238 \pm 77$ \\
\hline
\end{tabular}

$\mathrm{FS}=$ food supply; $\mathrm{n}=$ sample; $\mathrm{P}=$ Food Preference Index; $\mathrm{A}=$ average $\mathrm{C}=$ food consumption. 
D. branickii exhibited a stronger preference for $B$. oleracea than for C. moschata, T. esculentum, $M$. esculenta, C. lanats, Musa spp. and S. tuberosum $(\mathrm{p}<0.0001, \mathrm{~F}=20.6)$ (Figure 3$)$. There were no statistical differences in preference between I. batatas, C. papaya, C. moschata, M. esculenta, C. lanatus and T. esculentum ( $\mathrm{p} \geq 0: 05 ; \mathrm{F}=20.6$ ). In comparison with Musa spp. and $S$. tuberosum, just $C$. lanatus does not shown statistical differences between items $(\mathrm{p}<0.0001, \mathrm{~F}=20.6)$.

\section{Discussion}

Dinomys branickii feeds on fruit, leaves and stalks in the natural environment (NOWAK, 1991; SAAVEDRA-RODRÍGUEZ et al., 2012). This was also observed in the present study with a family group in captivity, as these foods represented a large part of the diet. Fruits were the most commonly consumed food, followed foods with high carbohydrate content (roots/tubers), the main source of dietary energy for homeostasis. Cuniculus paca was also found to prefer fruits that are rich in carbohydrates (ex. Mangifera indica $L$. and Persea americana), likely to maximize energetic gain (LASKA et al., 2003).
Evaluation of daily consumption and food preferences emphasized B. oleracea, T. esculentum and $Z$. mays as important components of the family group's diet. These foods contain satisfactory quantities of fiber (3.1 g/100 g, $4.5 \mathrm{~g} / 100 \mathrm{~g}$ and $3.9 \mathrm{~g} / 100 \mathrm{~g}$, respectively) (NEPA, 2015), suggesting that the main dietary components for this species are fibrous foods. This was also suggested by Osbahr and Mejía (2001), who showed that $D$. branickii possesses high digestive capacity for raw fibers. This was also found in other Hystricomorpha including: Dasyprocta sp. and H. hydrochaeris which have high nutrient absorption and digestive capacity due to fermentative digestion in the large intestine (cecum) (HENRY, 1999; RODRIGUES et al., 2006; McWILLIAMS, 2009). Osbahr and Mejía (2001) observed that Z. mays, C. moschata and Musa spp. had a Food Preference Index between 1.08 and 1.12. Values in the present study were similar $(1.10,1.25$, and 0.71 for C. moschata, Z. mays, and Musa spp., respectively). Despite the difference between the food groups offered in the both studies. One possible confounding factor for food preference is the experimental protocol allowing choices among different foods. This might have occurred in the present study with $S$. tuberosum, since D. branickii

FIGURE 3: Percent consumption of food items $(\mathrm{n}=10)$ in a food preference study for a captive Dinomys branickii family group. Statistical analysis yielded no differences between the column charts, represented graphically by traits shared.

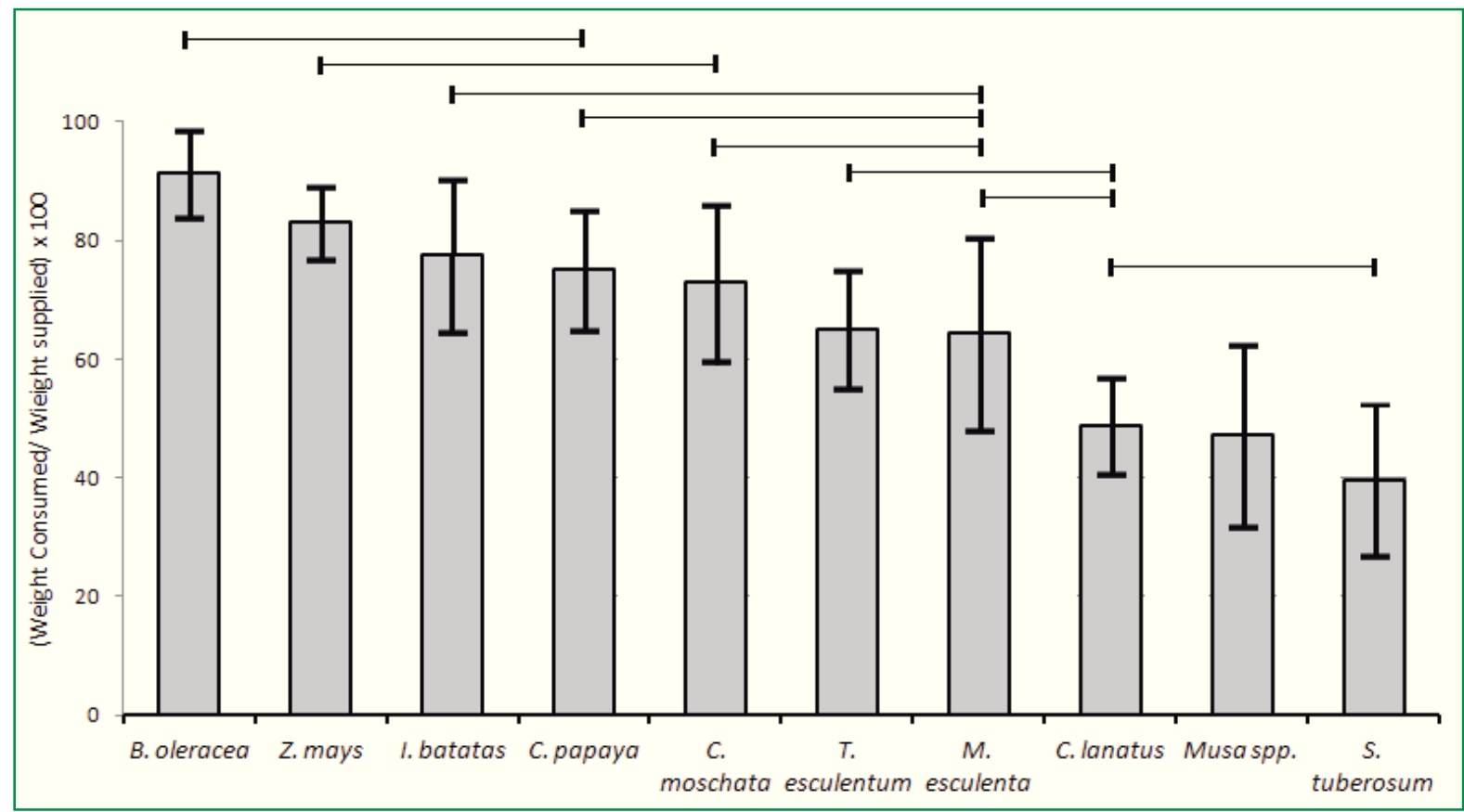


showed high consumption (82\%), but low preference $(\mathrm{P}=0.60)$ for this item compared to the other food items, despite being offered the same quantities during the consumption and food preference studies. However, additional studies are needed to investigate this idea.

D. branickii is selective for specific parts of plants, a behavior similar to that of other rodents such as Dasyprocta sp. (HENRY, 1999). These animals rejected the epicarp of C. moschata, I. batatas, S. tuberosum, Musa spp., M. indica L, C. lanatus and C. melo; and ingested only the carbohydrate-rich mesocarp in species such as C. pacas (ZUCARATTO et al., 2010); only seeds of $C$. sativus were consumed. This behavior was reported by OSBAHR and MEJÍA (2001) in which D. branickii ingested only the seeds of Sechium edule. The authors suggest that preferential seed consumption is due to high quantities of lipids.

There are only a few studies of $D$. branickii, thus it is crucial to continue studies that clarify behavioral nuances in captivity. Additional information will aid efforts of researchers who maintain these animals under permanent management, and can enhance our understanding of species biology in natural environments. Our results suggest that the diet of $D$. branickii in captivity should preferably contain roots/ tubers (S. tuberosum, I. batatas and M. esculenta) and fruits (M. comunis, C. moschata and C. papaya), foods with high carbohydrate content; leaves $(B$. oleracea and T. esculentum) and Z. mays, which present high quantities of fiber, proteins, and carbohydrates.

We highlight the need for a balanced and diverse diet for wild animals maintained in captivity. The diet should provide the essential nutrients to meet metabolic needs while maintaining vital functions, ensuring health, well-being, longevity and reproductive success and aiding species conservation.

\section{Acknowledgements}

The authors would like to thank the Conselho Nacional de Desenvolvimento Científico e Tecnológico (CNPq) for the scholarship grant from the Programa Institucional de Bolsas de Iniciação Científica (PIBIC); we thank the zoo owner Doctor Jorge Arthur Aarão
Monteiro for allowing access to and observation of animals at the Bioparque Amazônia Crocodilo Safari Zoo. We thank the zoo team, and the staff at the wildlife facility for practical assistance during research development. Financial support to Áurea Gabriel was provided by the Coordenação de Aperfeiçoamento de Pessoal no Ensino Superior (CAPES).

\section{References}

ANTONIO, S. D.; VELHO, J. P.; CARVALHO, P. A.; BACKES, A. A.; SANCHEZ L. M. B.; HAYGERT VELHO, I. M. P. Composição corporal e exigências líquidas em energia e proteína para ganho em peso de chinchilas (Chinchilla lanigera). Ciência e Agrotecnologia, Lavras, v. 31, n. 2, p. 479-484, 2007.

CARCIOFI, A. C.; OLIVEIRA, L. D. Doenças nutricionais. In: CUBAS, Z. S.; SILVA, J. C. R.; CATÃO-DIAS, J. L. (Ed.). Tratado de animais selvagens - Medicina Veterinária. São Paulo: Editora São Paulo, 2007. p. 838-864.

CAVALCANTE, R. R.; FIGUEIRÊDO, A. V.; CARVALHO, M. A. M.; LOPES, J. B.; ALMEIDA, M. M. Digestibilidade aparente de nutrientes de rações balanceadas com alimentos alternativos para cutias (Dasyprocta prymnolopha) em crescimento. Revista Ciência Animal Brasileira, Goiânia, v. 6, n. 3, p. 163-171, 2005.

CHEEKE, P. R.; DIERENFELD, E. S. Comparative animal nutrition and metabolism. Cambridge: CABI, 2010.338 p.

CHIARELlO, A. G.; AGUIAR, L. M. S.; CERQUEIRA, R.; MELO, F. R.; RODRIGUES, F. H. G.; SILVA, V. M. F. Mamíferos ameaçados de extinção no Brasil. In: MACHADO, A. B. M.; DRUMMOND, G. M.; PAGLIA, A. P. (Ed.). Livro vermelho da fauna brasileira ameaçada de extinção. Brasília/Belo Horizonte: MMA/Biodiversidade, 2008. p. 680-880.

COLLINS, L. R.; EISENBERG, J. F. Notes behaviour and breeding of pacaranas in captivity. International Zoo Yearbook, Malden, v. 12, p. 108-114, 1972.

CONSELHO NACIONAL DE PESQUISA. Other Rodents. In: FIEDLER, L. (Ed.). Microlivestock: little-known small animals with a promising economic future. Washington: National Academy Press, 1991. p. 277-282.

DIERENFELD, E. Captive wild animal nutrition: a historical perspective. Proceedings of the Nutrition Society, Edinburgh, v. 56, p. 989-999, 1997.

EMMONS, L. H.; FEER, F. Neotropical rainforest mammals - A field guide. Chicago: University of Chicago Press, 1990. 396 p.

HENRY, O. Frugivory and the importance of seeds in the diet of the orange-rumped agouti (Dasyprocta leporina) in french Guiana. Journal of Tropical Ecology, Winchelsea, v. 15, p. 291-300, 1999.

IUCN. International Union for Conservation of Nature. 2015. Disponível em: <http://www.iucn.org>. Acesso em: 16 out. 2015.

LASKA, M.; LUNA-BALTAZAR, J. M. B.; RODRIGUEZ-LUNA, E. Food preferences and nutrient composition in captive pacas, Agouti paca (Rodentia, Dasyproctidae). Mammalian Biology, Jena, v. 68, p. 31-41, 2003. 
LÓPEZ, L.; LÓPEZ, I.; MORA, J.; OSBAHR, K. Estudio preliminary del comportamiento de Dinomys branickii (Peters, 1873) en cautiverio. Revista Universidad de Ciencias Aplicadas y Ambientales, Actualidad y Divulgación Científica, Bogotá, v. 3, n. 1, p. 28-35, 2000.

McWILLIAMS, D. A. Determinants for the diet of captive agoutis (Dasyprocta spp.). Veterinary Clinics Exotic Animal, College Station, v. 12, p. 279-286, 2009.

NATIONAL RESEARCH COUNCIL. Guide for the care and use of laboratory animals. Washington: National Academies Press, 2011. $220 \mathrm{p}$.

NOWAK, R. W. Rodentia. In: NOWAK, R. W. (Ed.). Walker's mammals of the world. Baltimore \& London: Johns Hopkins University. 1991. p. 895-968.

NEPA - NÚCLEO DE ESTUDOS E PESQUISAS EM ALIMENTAÇÃO. Tabela Brasileira de Composição de Alimentos - TACO. 2015. Disponível em: $<$ http://www.unicamp. br/nepa/taco >. Acesso em: 16 out. 2015.

OSBAHR, K.; MEJÍA, D. R. Determinación de calico, hierro, protein y otros requerimientos de nutrients de Dinomys branickii (Peters, 1873). Revista Universidad de Ciencias Aplicadas y Ambientales Actualidad y Divulgación Científica, Bogotá, v. 4, n. 1, p. 44-55, 2001.

PACHECO, V.; SALAS, E.; CAIRAMPOMA, L.; NOBLECILLA, M.; QUINTANA, H.; ORTIZ, F.; PALERMO, P.; LEDESMA, R. Contribución al conocimiento de la diversidad y conservación de los mamíferos en la cuenca del río Apurímac, Perú. Revista Peruana de Biologia, Lima, v. 14, n. 2, p. 169-180, 2007.
PERISSÉ, M.; FONSECA, C. R. S. D.; CERQUEIRA, R. Diet determination for small laboratory-housed wild mammals. Canadian Journal of Zoology, Ottawa, v. 67, p. 775-778, 1989.

RODRIGUES, S. S.; FONSECA, C. C.; PAUlA, T. A. R.; PEIXOTO, J. V. Aspectos biométricos corporais e do intestino delgado da capivara Hydrochoerus hydrochaeris Linnaeus, 1766 (Mammalia, Rodentia, Hydrochaeridae). Biotemas, Florianópolis, v. 19, n. 3, p. 79-86, 2006.

SAAVEDRA-RODRÍGUEZ, C. A.; KATTAN, G. H.; OSBAHR, K.; HOYOS, J. G. Multiscale patterns of habitat and space use by the pacarana Dinomys branickii: factors limiting its distribution and abundance. Endangered Species Research, Oldendorf, v. 16, p. 273-281, 2012.

SÁNCHEZ, F.; SÁNCHEZ-PALOMINO, P.; CADENA, A. Inventario de mamífero en un bosque de Los Andes Centrales de Colombia. Caldasia, Bogotá, v. 26, n. 1, p. 291-309, 2004.

TIRIRA, D.; VARGAS, J.; DUNNUM, J. The IUCN red list of threatened species. 2008. Disponível em: $<\mathrm{http}: / / \mathrm{dx}$.doi. org/10.2305/IUCN.UK.2008.RLTS.T6608A12790614.en>. Acesso em: 19 nov. 2015.

ZUCARATTO, R.; CARRARA, R.; SIQUEIRA-FRANCO, B. K. Dieta da paca (Cuniculus paca) usando métodos indiretos numa área de cultura agrícola na Floresta Atlântica brasileira. Biotemas, Florianópolis, v. 23, n. 1, p. 235-239, 2010. 